\title{
KRITINIO MĄSTYMO TAIKYMAS KONSULTANTO VEIKLOJE
}

\author{
Dr. Gitana Tolutiene \\ Klaipedos universitetas \\ Giedrè Buteniené \\ Ukmergès užimtumo tarnyba \\ DOI: https://doi.org/10.52320/svv.v0iVI.204
}

\begin{abstract}
Anotacija
Šio straipsnio reikšmė grindžiama darbo, socialiniu kontekstu, kadangi analizuojamas kritinio mąstymo taikymas užimtumo tarnyboje konsultanto veiklos aspektu. Atskleidžiami kritinio mąstymo taikymo aspektai konsultanto veiklos aspektu užimtumo tarnyboje, išanalizuojant kritinio mąstymo sampratos teorines koncepcijas bei išnagrinėjant kritinio mąstymo taikymą užimtumo tarnyboje dirbančių konsultantų patirties atžvilgiu. Igyvendinant tyrimo tikslą, taikyta teorinė analizè ir kokybinis tyrimas (iš dalies struktūruotas interviu). Straipsnyje pateikiami atsakymai, ar pakankamai tirtos užimtumo tarnybos konsultantai supranta kritinio mąstymo taikymo konsultavimo metu svarbą ir prasmę, kokie kritinio mąstymo gebejjimai turi ịtakos konsultanto veiklos kokybei, kokie veiksniai lemia kritinio mąstymo ịgyvendinimą, kokius būdus ir priemones naudoja kritinio mąstymui taikymui ir kt. Pagrindiniai tyrimo rezultatai ir išvados pagrindžia tai, jog tirtoje užimtumo tarnyboje dirbančių konsultantų kritinis mąstymas svarbus konsultavimo kokybei, veiksmingo grịžtamojo ryšio teikimui, patirties refleksijai, savęs pažinimui, savo privalumų, trūkumų ir tobulintinų veiklos aspektų analizei.
\end{abstract}

Pagrindiniai žodžiai: kritinis mąstymas, konsultantas, užimtumo tarnyba.

\section{Ivadas}

Temos aktualumas. Aktualizuojant kritinio mąstymo svarbos klausimą konsultantui, tarptautinès mokslinès konferencijos „The International Business Conference 2016: Searching for Innovative and Creative Business Solutions“ medžiagoje pabrěžiama, jog kritinis mąstymas ịgalina pačius darbuotojus ieškoti naujų, originalių, nešabloniškų sprendimų. Šiuo metu pasauliui reikalingi darbuotojai, turintys kritini mąstymą, gebantys bendrauti, suvokti problemas, priimti sprendimus ir prisitaikyti prie naujos, sparčiai besikeičiančios aplinkos. Todẻl šiame straipsnyje nagrinėjamos temos aktualumas neabejotinas. Ši faktą patvirtina ir tai, jog konsultanto veikla užimtumo tarnybos kontekste iki šiol nenagrinèta.

Remiantis 2019 metais PwC (Price Waterhouse Coopers) leidinyje „Forbes“ (forbes.com, 2019) Westfall‘o paskelbto tyrimo duomenimis, 77 proc. įmonių vadovų ieško, tačiau dažnai neranda asmenų, turinčių aukštą kritinio mąstymo kompetenciją. Todèl tampa aktualu bandyti šią kompetenciją plètoti jau darbo aplinkoje su esamais darbuotojais. Juk iš esmès kritinis mąstymas yra gebèjimas ir siekis įvertinti teiginius ir priimti objektyvius sprendimus, remiantis gerai pagrịstomis priežastimis. Tai yra vienas iš emocinio intelekto veiksnių, galinčių nulemti darbuotojo indèli i i organizaciją.

Tyrimo problema. Tyrimai (Price waterhouse Coopers, 2019; Searching for Innovative and Creative Business Solutions, 2016 ir kt.) rodo, jog kritini mąstymą ịvaldę darbuotojai pasižymi lankstumu, veiklumu, netradiciniu ir savarankišku mąstymu, gebejjimu prisitaikyti, poreikiu tobulinti savo veiklą, greitai orientuotis sudètingose situacijose, lengvai ir netipiškai spręsti problemas, siekti pokyčių, igyti patirties, yra atviri naujovèms. Tuo tarpu kritinio mąstymo taikymo stoka darbo aplinkoje sukuria neigiamų padarinių seką, žalingai veikiančių ne tik darbuotojus, bet ir klientus. Todèl šiame straipsnyje siekiama atsakyti i probleminius klausimus: ar pakankamai užimtumo tarnybos konsultantai supranta kritinio mąstymo taikymo konsultavimo metu svarbą ir prasmę? kokie kritinio mąstymo gebejimai turi įtakos konsultanto veiklos kokybei ir kokie veiksniai lemia kritinio mąstymo igyvendinimą? kokius būdus ir priemones naudoja kritinio mąstymui taikymui?

Tyrimo objektas: kritinio mąstymo taikymas konsultanto veiklos aspektu.

Tyrimo tikslas: atskleisti kritinio mąstymo taikymą konsultanto veiklos aspektu užimtumo tarnyboje.

Tyrimo uždaviniai:

1) išanalizuoti kritinio mąstymo sampratos teorines koncepcijas;

2) išnagrinèti kritinio mąstymo taikymą užimtumo tarnyboje dirbančių konsultantų patirties atžvilgiu. 
Tyrimo metodai: teorinè analizè, naudota siekiant atskleisti kritinio mąstymo sampratų ịvairovę ir esmę; kokybinis tyrimas (iš dalies struktūruotas interviu), taikytas siekiant išanalizuoti kritinio mąstymo taikymą užimtumo tarnyboje konsultantų veiklos aspektu.

\section{Kritinio mąstymo sampratų ịvairovẻ ir esmė}

Analizuojant kritinio mąstymo sampratą, pirmiausia svarbu išsiaiškinti sąvoką „kritinis“. Kaip nurodoma Lietuvių kalbos žodyne, „kritinis“ - tai žodis, turintis lemiamos reikšmès reiškiniams (lkz.lt) arba tam tikrų kritiškumo elementų, tačiau tai - tik vienas elementas iš daugelio (Juris Belte). Pati kritinio mąstymo sąvoka kildinama iš graikiškų žodžių „kritikos“ - įžvalgus protas, nuovokumas ir „kriterion“ - kriterijus, arba tam tikras matas, standartas. Sujungus šias sąvokas galima teigti, kad kritinis mąstymas reiškia ịžvalgų protą ar protavimą (samprotavimą) remiantis tam tikrais kriterijais, grindžiamas įsitikinimu, kad daugeliu atvejų nėra iš anksto parengtų ir apibréžtų atsakymų - juos atrasti turi pats asmuo aktyviai ir iš esmès apmąstydamas net pačius paprasčiausius reiškinius, kurie vèliau gali pasirodyti ir ne tokie paprasti (Penkauskienè, 2016).

Kritinis mąstymas gali būti analizuojamas ir kaip filosofijos, ir kaip psichologijos, ir kaip edukologijos objektas. Filosofiniame požiūryje atsispindi menas suderinti daugybę procesų, psichologiniame požiūryje ị kritinị mąstymą išryškinami gebejjimai, panaudojant mąstymo operacijas, problemų suvokimui ir sprendimui sujungiant mąstymo bei jausmų vienovę, edukologiniu požiūriu tai aktyvus pažinimo procesas, kurio pasekmé - mąstymo tobulinimas.

Nors negalime paneigti, kad kritiniame mąstyme yra kritiškumo elementų, kritinis mąstymas nereiškia visko neigti. Tai - pozityvus mąstymas, reiškiantis, kad pastebime tam tikras galimybes. Jis reikalingas būtent tam atskirti ir pamatyti, ị kokią informaciją verta kreipti dèmesị. Pasak Penkauskienès (2016), kritinis mąstymas nuo antikos laikų savo prigimtimi buvo demokratiškas teigiantis žmogaus prigimtinị norą ir galias pažinti disciplinuoto proto ir gilaus, laisvo bei kryptingo mąstymo vertę asmeniui ir visuomenei. Apžvelgiant raidos aspektu Šiaurès Amerikos tyrèjų požiūrị i kritinị mąstymą, reikètų išskirti Paul'o ir Elder'io (2012), kurie prie ịprastų analitinių ir metamąstymo gebejjimų priduria intelektinę empatiją, intelektinị kuklumą, asmenybès integralumą kaip turinčius stiprų moralinị, etinị ir vertybinị pagrindą. Jų požiūriu, kritiškai mąstančios asmenybès priskiriamos dorai mąstantiems žmonėms - neindiferentiškiems, nesavanaudžiams, nedemonstruojantiems intelektinio pranašumo. Tuo tarpu Facione ir jo kolegos (2010) išskiria septynias pagrindines kritinio mąstymo dispozicijas (1 pav.), kurių pagrindu galima teigti, kad tuometiniai tyrëjai į kritini mąstymą žvelgè per asmeninių polinkių, nuostatų ar gebejjimų vertinimą. Atkreiptinas dèmesys, kad dažniausiai pasikartojantys bruožai, būdingi kritiškai mąstančioms asmenybèms, yra smalsumas ir atvirumas naujai patirčiai, gebejjimas susitelkus dirbti, drąsa rizikuoti ir prisiimti atsakomybę, neapibrèžtumo tolerancija, atvirumas įvairioms nuomonèms ir požiūriams, gebejjimas analizuoti ir reflektuoti.

Kritinis mąstymas laikomas vienu svarbiausių gebejjimų, sąlygojančių asmens ir visuomenès gerovę. Šiandien vis dažniau galima išgirsti kritinio mąstymo apibrēžimus įvairiais aspektais ir ịvairiose veiklos srityse: pradedant nuo pareigybių aprašymų, darbo skelbimų, seminarų ar net šnekamojoje kalboje. Tuo tarpu kritinio mąstymo teoretikai gana skirtingai ịvardija kritinị mąstymą, tačiau visus apibréžimus vienija ši fenomeną ịvaldžiusios asmenybės savybės: kryptingumas, sistemiškumas, atkaklumas ir ištvermingumas, savikontrolè, savirefleksija ir savęs tobulinimas, mąstymą lemiančių prielaidų reflektavimas ir ịvertinimas, analitiškumas ir kt. 


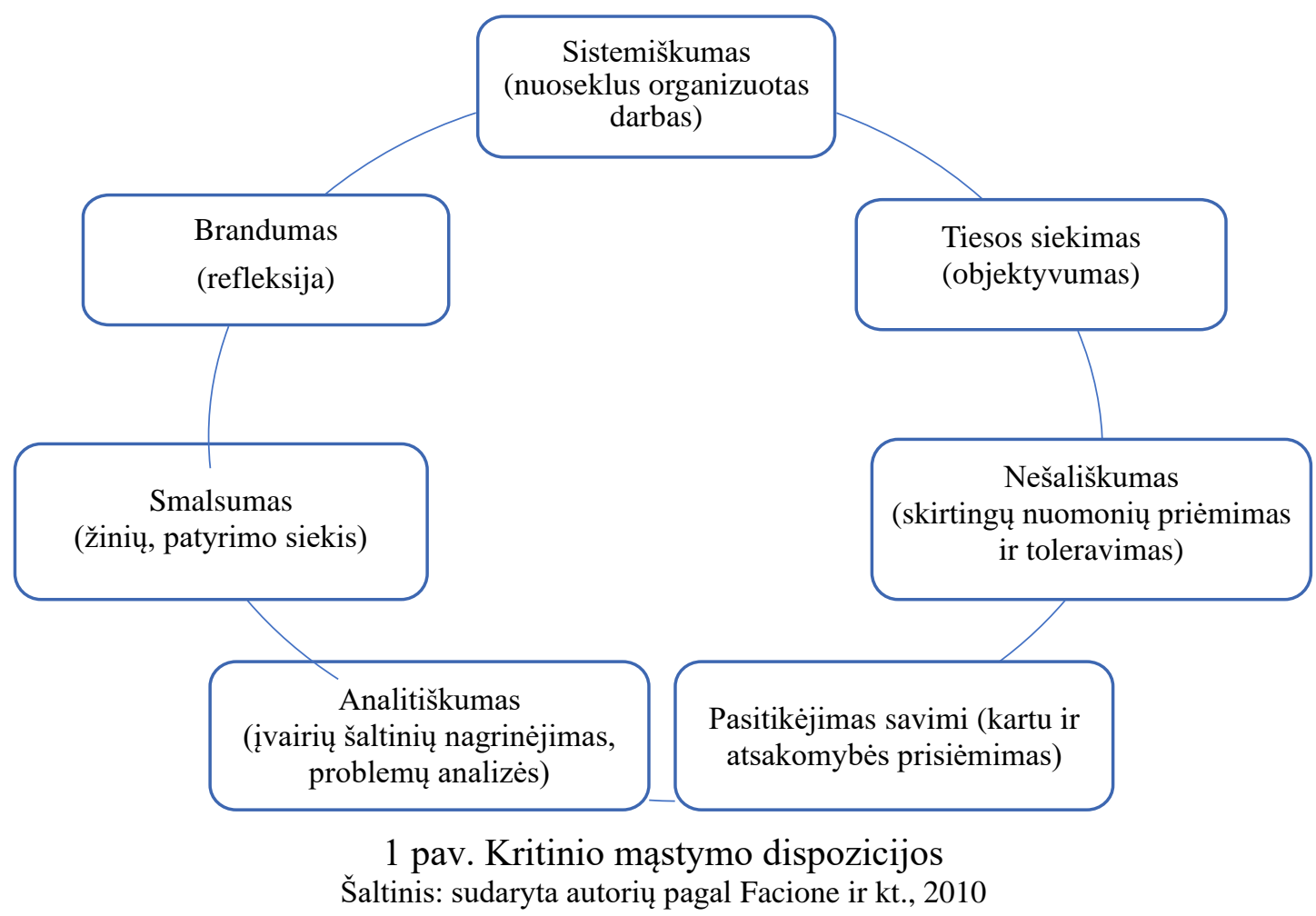

Pati sąvoka „kritinis mąstymas“ apima tiek daug gebejimų, veiklos ir vertybių, kad net sunku ją apibrèžti. Kritiškai mąstyti - tai priimti idejjas ir ieškoti jų prasmès, lyginti su priešingais požiūriais, kurti ịtikinamas sistemas joms pagrịsti ir remtis šiomis struktūromis savo veikloje. Tai asmens mąstymo būdas, leidžiantis analizuoti, kurti ir ịvertinti savo pačių pagrindines prielaidas, tikslus, prasmes. Kritini mąstymą ịvaldę darbuotojai padeda organizacijoms išlikti sprendžiant problemas bei priimant sprendimus, nes kritiškai mąstyti - tai apsvarstyti kitokị požiūrị, būti smalsiam, taikyti ivvairias tiriamąsias strategijas, kelti probleminius klausimus ir nuosekliai bei sistemingai ieškoti atsakymu.

Helsdingen'as ir kt. (2011) pabrěžia, jog kritinis mąstymas - tai aukšsto lygmens mąstymas, ieškant išsamios sprendimo analizès, tai mąstymas, reikalaujantis analizès, sintezès ir refleksijos (Halpern, 2014), atvirumo ir sąmoningumo (Huang ir kt., 2016). Ku ir kt. (2014) kritini mąstymą apibūdina kaip kognityvinius gebejjimus, kurie sudaro pagrindą loginiam mąstymui ir argumentavimui, ir atspindi asmens ịgūdị realizuoti šiuos gebejjimus (Huang ir kt., 2016).

Tiruneh'as ir kt. (2017) kritini mąstymą sieja su protavimu, analizavimu, numatymu ir kitais mąstymo procesais. Loes'o ir Pascarella'os (2017) teigimu, kritinis mąstymas yra analitinių ir sintetiniu gebejjimų visuma. Analitiniai gebėjimai sudaro argumentų struktūros analizę, apimančią išvadų ir atskirų argumento elementų funkcijų ir įrodymų pagrịstumo identifikavimą, o sintetiniai gebejimai apima prasmingų argumentų plètojimą atrenkant informaciją, reikalingą jų pagrindimui.

Pažymima, kad kritinio mąstymo gebẻjimai leidžia žmogui sèkmingai dirbti savo profesijoje (Kumar ir James, 2015), atsakingai priimti sprendimus atsižvelgiant ị sudètingas realaus gyvenimo problemas ir tapti sumanios visuomenès nariu (Halpern, 2014). Todèl pati sąvoka „kritinis mąstymas“ ir gebëjimas jị pritaikyti kasdieniame gyvenime tampa neatsiejama šių dienų misija jau vien dèl to, kad kritinis mąstymas ịgalina nepriklausomai ir savarankiškai mąstyti.

Kadangi, nagrinėjant užsienio tyrẻjų kritinio mąstymo sampratu ịvairovę, atskleista, jog jis laikomas reflektyvaus mąstymo procesu, todėl refleksija neatsietina nuo kritinio mąstymo. „Refleksija - savo patirties, žinių bei įsitikinimų kritinis apmąstymas, susietas su nauja patirtimi ir žiniomis, skatinantis ateities veiksmu modeliavimą“ (Zafar ir kt., 2014, p. 14). Refleksija suvokiama kaip mąstymo būdas, kai asmuo kritiškai analizuoja, ịsisąmonina ir ịprasmina savo mąstymo turinį, formas ir prielaidas, savo dvasinio pasaulio sandarą ir ypatybes (Vaicekauskienè ir Čiužas, 2013). Beachboard'as ir kt. (2011) nurodo, jog kritinis mąstymas yra reflektyvus problemų sprendimo procesas, apimantis tokius pažintinio mąstymo procesus kaip gebëjimą daryti išvadas, analizuoti 
veiklos problemas (Tiruneh ir kt., 2017). Kritinis mąstymas - tai gebëjimas įvairiapusiškai analizuoti ir ịvertinti situaciją bei idejas, kad būtų pasirenkama protinga ir pagrịsta pozicija, svarbus ne tik mokantis, bet ir vertinant save, savo gebejjimus, bendraujant, t. y. atliekant savo veiklos analizę, ir yra reflektyvaus mąstymo, leidžiančio ịvertinti, ką reiškia tai, kas buvo sužinota, pamatyta, patirta, savaime neatsiranda ir nesireiškia, pagrindas. Taigi, kritinis mąstymas - reflektyvaus mąstymo pagrindas, o reflektyviai mąstyti - tai pritaikyti savo kritinio mąstymo gebejjimus. Anot Ford'o ir Yore (2012), kritinis mąstymas yra refleksijos procesas, kuris kelia iššūkius turimoms idejoms ir tuo pačiu skatina diskutuoti pačiam su savimi. Tyrējai kritinị mąstymą pripažista kaip reflektyvų problemų sprendimo procesą, kai negalima nustatyti akivaizdžiai teisingo sprendimo. Tuo tarpu Halpern'o (2014) kritini mąstymą vertina ne tik kaip refleksijos procesą, bet ji gretina su prasmingų argumentų plètojimu.

Apibendrinant galima teigti, jog kritinis mąstymas - tai aukštesnio lygmens mąstymas, kuomet pasitelkiamas protavimas, analizavimas, numatymas ir t. t.; tai sintetiniai gebejjimai, apimantys prasmingų argumentų plètojimą atrenkant svarbiausią informaciją; tai apmąstymas, susietas su nauja patirtimi ir žiniomis, skatinantis ateities veiksmų modeliavimą; tai reflektyvus problemų sprendimo procesas, apimantis tokius pažintinio mąstymo procesus kaip gebėjimus daryti išvadas, analizuoti veiklos problemas ir kt.

Kad konsultantas galètų visapusiškai pažinti žmogų, ji supančius procesus ir reiškinius, jis turi sugebėti kritiškai mąstyti, todèl kritinis mąstymas šiame straipsnyje aktualizuojamas kaip vienas esminių konsultanto veiklos proceso (kurio esmè - tinkamo kontakto ir palankios aplinkos sukūrimas, pagalba, parama, motyvavimas, analizė savęs, savo veiklos ir besikreipiančiųjų) komponentų, be kurio neįmanoma produktyvi konsultavimo veikla, igyvendinant ir užimtumo tarnybos siekiamas vertybes: empatiją, patikimumą, atsakingumą, atvirumą ir kt. Todèl aktualu tampa empiriniu tyrimu pagrissti kritinio mąstymo taikymą užimtumo tarnyboje andragogo konsultanto veiklos aspektu.

\section{Kritinio mąstymo taikymo užimtumo tarnybos konsultantų veikloje tyrimas}

\subsection{Tyrimo metodologija ir dalyvių demografinė charakteristika}

Tyrimo tikslas - empiriškai atskleisti kritinio mąstymo taikymą užimtumo tarnyboje dirbančių konsultantų patirties atžvilgiu.

Tyrimo tipas. Pasirinktas kokybinis tyrimo tipas, kai duomenys pateikiami aprašant, o ne skaičių pavidalu, todèl, kad šiuo tyrimu nustatomos konsultantų vertybės, požiūriai, patirtys, ieškoma atsakymų i klausimą „kodèl“. Temose ir kategorijose atsispindi ìvairialypé realybè, kuri yra priklausoma nuo subjektyvaus tyrëjo suvokimo interpretuojant tyrimo dalyvių tekstus (Žydžiūnaitė ir Sabaliauskas, 2017).

Tyrimo etapai. Siekiant išsikelto tikslo, sudarytas tyrimo igyvendinimo planas: pirmame tyrimo etape, remiantis mokslinių šaltinių ir dokumentų analize, parinkta tyrimo metodika; antrame sudarytas interviu klausimynas, numatyta tyrimo vieta, imties kontingentas ir kt.; trečiame - vykdytas interviu; ketvirtame - atlikta gautų duomenų kokybinè analizė bei interpretacija; penktame tyrimo etape formuluojamos išvados.

Tyrimo imtis. Kokybiniam tyrimui pasirinkti 9 užimtumo tarnybos įdarbinimo ir užimtumo rèmimo konsultantai, kuomet iš viso šios tarnybos skyriuje, priklausančiame Vilniaus užimtumo tarnybai, dirba 13 skirtingų konsultantų: įdarbinimo, karjeros, informavimo ir užimtumo rèmimo. Tyrimo dalyviai pasirinkti naudojant netikimybini atrankos metodą, taikant tikslinę atrankos strategiją, kuri, anot Žydžiūnaitès ir Sabaliausko (2017), reiškia, kad tyrèjai, atsižvelgiant ị tyrimo metodą, gali pasirinkti subjektus. Kiti konsultantai dèl padidejusio darbo krūvio arba asmeninių priežasčių nesutiko dalyvauti tyrime ar neatitiko atrankos kriterijų. Pagrindiniai tyrimo dalyvių atrankos kriterijai: profesionalūs (aukštaji išsilavinimą turintys) konsultantai; konsultantai, turintys ne mažiau nei penkerių metų darbo stažą užimtumo tarnyboje.

Tyrimo dalyvių amžius svyruoja nuo 36 iki 56 metų, amžiaus vidurkis - 46 metai. Visų tyrimo dalyvių lytis moteriška, visi igiję aukštajj išsilavinimą ir visų darbo patirtis užimtumo tarnyboje siekia 
daugiau nei penkerius metus, t. y. svyruoja nuo 6 iki 26 metų, kas atskleidžia jų profesionalumą profesinèje veikloje (1 lentelè).

1 lentelè. Tyrimo dalyvių demografinè charakteristika

\begin{tabular}{|c|c|c|c|c|}
\hline Pareigos & Amžius & Lytis & Išsilavinimas & Darbo patirtis \\
\hline Konsultantas (1) & 36 & M & Aukštasis & $8 \mathrm{~m}$. \\
\hline Konsultantas (2) & 55 & M & Aukštasis & $13,4 \mathrm{~m}$. \\
\hline Konsultantas (3) & 36 & M & Aukštasis & $6 \mathrm{~m}$. \\
\hline Konsultantas (4) & 50 & M & Aukštasis & $18 \mathrm{~m}$. \\
\hline Konsultantas (5) & 47 & M & Aukštasis & $13 \mathrm{~m}$. \\
\hline Konsultantas (6) & 51 & M & Aukštasis & $26 \mathrm{~m}$. \\
\hline Konsultantas (7) & 47 & M & Aukštasis & $23 \mathrm{~m}$. \\
\hline Konsultantas (8) & 38 & M & Aukštasis & $9,5 \mathrm{~m}$. \\
\hline Konsultantas (9) & 56 & M & Aukštasis & $25 \mathrm{~m}$. \\
\hline
\end{tabular}

Šaltinis: sudaryta autorių pagal atlikto tyrimo duomenis, 2021.

Tyrimo metodai. Kokybinis tyrimo metodas, kurị taikant siekiama suprasti, kaip individai suvokia pasauli ir kaip individualiai kuriamos prasmès lemia jų elgesį (Žydžiūnaitè ir Sabaliauskas, 2017). Tyrimo duomenims rinkti taikytas pusiau struktūruotas interviu - tai duomenų rinkimo metodas, apimantis tyrimo dalyvių klausinejjimą ir aktyvų jų atsakymų klausymąsi, siekiant suvokti jų patirtį ir sužinoti nuomones tiriamuoju klausimu (Žydžiūnaitè ir Sabaliauskas, 2017). Interviu su konsultantais buvo įrašomas diktofonu gavus jų sutikimą. Pusiau struktūruoto interviu pasirinkimą nulèmè tai, kad interviu metu gaunami atviri tyrimo dalyvių atsakymai, atskleidžiantys jų požiūrị, nuomonę, jausmus, žinias bei patirtį. Tyrimui išanalizuoti pasirinkta kokybinès turinio analizès strategija, kuria gilinamasi ị objektą ir kontekstą, domintis panašumais bei skirtumais tarp kategorijų ar kodų (Gaižauskaitė ir Valavičienè, 2016). Gauti rezultatai suskirstyti i prasminius vienetus kategorijas bei analizuojami įtraukiant i nagrinëjamo reiškinio kontekstą. Kokybės turinio analizei atlikti taikyti etapai: kategorijų išskyrimas, interviu sakinių ir žodžių analizė; kategorijų skaidymas ị elementus; prasminių elementų suskirstymas i subkategorijas; turinio duomenų interpretavimas. Taikytas lyginamasis metodas, grindžiantis teiginius apie objektų, reiškinių panašumus ir skirtumus, lyginant skirtingų mokslininkų nuomones, atliktus tyrimus, susijusius su tiriamuoju objektu. Pusiau struktūruoto interviu duomenys buvo analizuojami, lyginami, vertinami pasitelkiant literatūros šaltinių analizę, atskleidžiant sąsajas tarp teorijos ir faktų.

Tyrimo instrumentas - klausimynas. Iš anksto apsvarstytos pagrindinès interviu klausimyno temos, kurias siekiama aptarti, bei svarbiausi kiekvienos temos klausimai. Klausimyną sudaro tyrimo dalyvių demografinè charakteristika (4 klausimai) ir 5 diagnostiniai klausimai (2 lentelè).

2 lentelè. Pusiau struktūruoto interviu klausimyno analizè

\begin{tabular}{|c|c|c|}
\hline Klausimyno blokai & Tema & Klausimai \\
\hline $\begin{array}{l}\text { Tyrimo dalyviu } \\
\text { charakteristika }\end{array}$ & Amžius, lytis, išsilavinimas, darbo patirtis Užimtumo tarnyboje & Nenumeruojami \\
\hline $\begin{array}{l}\text { Diagnostiniai } \\
\text { klausimai }\end{array}$ & $\begin{array}{l}\text { 1. Kaip suprantate kritinio mąstymo taikymą konsultavimo metu? } \\
\text { 2. Kokia kritinio mąstymo taikymo svarba bei prasmè užimtumo } \\
\text { tarnyboje dirbantiems konsultantams? } \\
\text { 3. Kaip manote, kokiais gebejjimais išsiskiria konsultantas, turintis } \\
\text { kritinị mąstymą? } \\
\text { 4. Kokie, Jūsų nuomone, yra efektyviausi kritinio mąstymo taikymo } \\
\text { būdai ir priemonès? } \\
\text { 5. Kokius būdus ir priemones naudojate igyvendindami kritinio } \\
\text { mastymo taikymą užimtumo tarnyboje? }\end{array}$ & $1,2,3,4,5$ \\
\hline
\end{tabular}

Šaltinis: sudaryta autorių pagal atlikto tyrimo duomenis, 2021

Tyrimo organizavimas ir etika. Tyrimo atlikimo metu dèl valstybejje paskelbtos ekstremalios situacijos (karantino), interviu vyko telefonu arba naudojant „Microsoft Teams“ programą, taip laikantis paskelbtų Vyriausybės nurodymų (likti namuose). Su kiekvienu informantu prieš interviu buvo kalbama asmeniškai, užduodant tyrimo dalyvių charakteristikos klausimus, pristatant tyrimo temą, paaiškinant tyrimo tikslą ir kt. Tam buvo skiriama $15 \mathrm{~min}$. Interviu trukmè - apie $60 \mathrm{~min}$. Prieš 
atliekant interviu su konsultantais tyrimo atlikimo galimybės buvo suderintos su užimtumo tarnybos vadovybe. Atliekant tyrimą laikytasi konfidencialumo, pagarbos asmens orumui, savarankiškumo, laisvo apsisprendimo, teisingumo ir anonimiškumo principų. Laikantis konfidencialumo principo informantai buvo užkoduoti tokiu būdu: K1; K2; K3; K4; K5; K6; K7, K8, K9. Interviu data ir laikas buvo suderinti iš anksto. Tyrimo dalyviams buvo garantuotas duomenų saugumas. Atliekant interviu nebuvo prašoma nurodyti savo vardo ir pavardès.

\subsection{Tyrimo rezultatų analizė ir interpretacija}

Atliekant tyrimą, aktualu buvo sužinoti, kaip tyrimo dalyviai supranta kritinio mąstymo taikymą konsultavimo metu. Gauti teiginiai grupuoti i kategoriją „Kritinio mąstymo taikymo samprata“ ir i 3 jos subkategorijas: „Tinkamų faktų apie klientą atrinkimas“, „Greitas informacijos ịvertinimas ir suteikimas klientui“, „Tikslus kliento poreikių išsiaiškinimas ir pagalbos suteikimas“ (3 lentelè).

3 lentelè. Kritinio mąstymo taikymo samprata

\begin{tabular}{|c|c|c|}
\hline Kategorija & Subkategorija & Patvirtinantis teiginys \\
\hline \multirow{16}{*}{$\begin{array}{l}\text { Kritinio mąstymo } \\
\text { taikymo samprata }\end{array}$} & \multirow{4}{*}{$\begin{array}{c}\text { Tinkamų faktų } \\
\text { apie klientą } \\
\text { atrinkimas }\end{array}$} & „Konsultuojant svarbu mokèti atsirinkti tinkamus faktus [...]““ (K1) \\
\hline & &,$[\ldots]$ atsirenkant, ar pateikta kliento informacija yra teisinga [...]“ (K3) \\
\hline & & ,[...] padèties detalus ịvertinimas, analizè [...]“ (K4) \\
\hline & &,$[\ldots]$ tinkamai išgirsti klientą $[\ldots]$ “.. $(\mathrm{K} 1)$ \\
\hline & \multirow{4}{*}{$\begin{array}{c}\text { Greitas } \\
\text { informacijos } \\
\text { ivertinimas ir } \\
\text { suteikimas klientui }\end{array}$} & $\begin{array}{l}\text { „Reikia ivvertinti esamą situaciją labai greitai ir suteikti reikiamą } \\
\text { informaciją klientui }[\ldots]^{“}(\mathrm{~K} 1)\end{array}$ \\
\hline & &,$[\ldots]$ Pateiktos informacijos greitas ir tinkams įvertinimas $[\ldots]^{“}(\mathrm{~K} 3)$ \\
\hline & & $\begin{array}{l},[\ldots] \text { turimų igūdžių tobulinimas ir/ar naujų suteikimas, pritaikymas } \\
[\ldots]]^{“}(\mathrm{~K} 4)\end{array}$ \\
\hline & & „[...] asmens galimybių ir norų išsiaiškinimas [...]“ (K9) \\
\hline & \multirow{8}{*}{$\begin{array}{l}\text { Tikslus kliento } \\
\text { poreikių } \\
\text { išsiaiškinimas ir } \\
\text { pagalbos } \\
\text { suteikimas }\end{array}$} & $\begin{array}{l}\text { „[...] Nedaryti išvadų neišklausius kliento, tiksliai išsiaiškinti } \\
\text { pageidavimus ir poreiki }[\ldots]^{\prime “}(\mathrm{~K} 2)\end{array}$ \\
\hline & &,$[\ldots]$ suteikti kvalifikuotą paslaugą pagal poreiki" $(\mathrm{K} 2)$ \\
\hline & & „Asmens įterpimas i aukštesni lygi socialinèje plotmèje [...]“ (K4) \\
\hline & & $\begin{array}{l}\text { „[...] kokybiškai suteikti individualiam klientui reikalingą pagalbą [...]“" } \\
\text { (K5) }\end{array}$ \\
\hline & & $\begin{array}{l}\text { „[...] paslaugų parinkimas klientui pagal jų išsilavinimą, darbinę patirtį } \\
{[\ldots]^{\prime \prime}(\mathrm{K} 6)}\end{array}$ \\
\hline & & $\begin{array}{l}\text {,[...] nustatyti kliento tam tikrus sugebėjimus, galimybes, poreikius“ } \\
\text { (K7) }\end{array}$ \\
\hline & & „Kliento poreikių išaiškinimas, problemų sprendimas“ (K8) \\
\hline & & $,[\ldots]$ suprasti kliento poreikius $[\ldots]]^{“}(\mathrm{~K} 1)$ \\
\hline
\end{tabular}

Šaltinis: sudaryta autorių pagal atlikto tyrimo duomenis, 2021

Kaip matyti 3 lentelèje, interviu metu tyrimo dalyviai nurodè, jog kritinio mąstymo taikymas konsultanto veikloje - tai ,,...] tinkamų faktų apie klientą atrinkimas, ịvertinimas, analizè [...]“ (K4), kuomet itin ,[...] svarbu ne tik mokèti atsirinkti tinkamus faktus $[\ldots]^{\text {“ }}(\mathrm{K} 1)$, bet ir ,[...] ar pateikta kliento informacija yra teisinga [...]“" (K3). Tai rodo, jog kritinis mąstymas yra svarbus konsultanto gebejjimas, kuris kaip vienas pagrindinių bendravimo įrankių padeda jam atsirinkti teisingą informaciją iš pateikiamų kliento lūkesčių ir išsakomų poreikių, reflektuoti ir priimti tinkamus sprendimus, kuomet ne mažiau svarbu gebejjimas klausyti, klausytis ir išgirsti tai, ką klientas sako ar nori pasakyti. Pasak tyrimo dalyvių, kritinio mąstymo taikymas - tai greitas informacijos įvertinimas ir suteikimas klientui, nes kritinis mąstymas yra būtinas, siekiant, ,[...] ịvertinti esamą situaciją labai greitai ir suteikti reikiamą informaciją klientui $[\ldots]^{\text {“ }}(\mathrm{K} 1)$. Pagal kitus gautus duomenis galima teigti, jog kritinio mąstymo taikymas konsultavimo metu yra tikslus kliento poreikių išsiaiškinimas ir pagalbos suteikimas, siekiant padèti jam apsispręsti dèl tinkamo profesijos pasirinkimo ar ieškomo darbo. Šiuo aspektu informantai nurodo, jog svarbu ,,[...] suprasti kliento poreikius [...]“ (K1), ,[...] nedaryti išvadų neišklausius kliento [...]“ (K2), ,[...] suteikti kvalifikuotą konsultavimo paslaugą“ (K2) ir kt. Tuo remiantis, galima teigti, jog konsultavimo metu svarbu išklausyti klientą, suprasti jo poreikius, nedaryti išankstinių išvadų, kadangi tinkamai ịvertinta informacija apie klientą veda prie kokybiškos pagalbos 
suteikimo. Tik kritiškai mąstantis konsultantas geba įvertinti kliento suteiktos informacijos patikimumą ir suteikti aukštos kokybès poreikių, lūkesčių bei galimybių ịvertinimą klientui. Išanalizavus gautus duomenis (3 lentelè), paaiškèjo, jog tyrimo dalyviai kritinio mąstymo taikymą konsultavimo metu supranta kaip tinkamų faktų apie klientą atrinkimą, greitą informacijos įvertinimą ir suteikimą klientui, tikslų kliento poreikių išsiaiškinimą ir pagalbos suteikimą. Tačiau, remiantis atliktų tyrimų rezultatais (Helsdingen ir kt., 2011; Tiruneh ir kt., 2017 ir kt.), tenka konstatuoti, jog kritinio mąstymo taikymas konsultanto veikloje - tai ne tik kliento informacijos ịvertinimas, poreikių išsiaiškinimas, pagalbos suteikimas, bet ir aukšto lygmens konsultanto mąstymas, glaudžiai susijęs su protavimu, analizavimu, numatymu ir visų pirma taikomas, ieškant informacijos apie kliento poreikius bei sprendimo analizès, siekiant prasmingos pagalbos klientui. Taip pat svarbu akcentuoti, kad kritinis mąstymas yra gebėjimas, leidžiantis ịvertinti gaunamą informaciją, todèl jis toks svarbus konsultanto veikloje, nes kritiškai mąstantis konsultantas prieš pradėdamas naudotis gauta kliento informacija, galvoja, tikrina ją, nagrinejja alternatyvas, faktus, prielaidas ir nesilaiko išankstinių nuostatų.

Atliekant tyrimą siekta atskleisti, kokia yra kritinio mąstymo taikymo svarba bei prasmè užimtumo tarnyboje dirbantiems konsultantams. Tyrimo dalyvių teiginiai sugrupuoti i kategoriją „Kritinio mąstymo taikymo svarba ir prasmė konsultanto veikloje“ ir i 6 subkategorijas: „Konsultantu tobulëjimas savo veikloje“, „Konsultantų savęs įsivertinimas“, „Klientų ịvertinimas“, „Profesinio pasitikèjimo igijimas“, „Klientams svarbios informacijos perteikimas“, „Konsultantu kokybiškos veiklos atlikimas“"(4 lentelè).

4 lentelè. Kritinio mąstymo taikymo svarba ir prasmè konsultanto veikloje

\begin{tabular}{|c|c|c|}
\hline Kategorija & Subkategorija & Patvirtinantis teiginys \\
\hline \multirow{15}{*}{$\begin{array}{l}\text { Kritinio mąstymo } \\
\text { taikymo svarba ir } \\
\text { prasmé }\end{array}$} & \multirow[t]{2}{*}{$\begin{array}{l}\text { Konsultantų tobulejjimas } \\
\text { savo veikloje }\end{array}$} & $\begin{array}{l}\text { "[...] kad konsultantai galètų tobulèti, jiems reikia kasdien } \\
\text { taikyti kritini mąstymą [...]" (K1) }\end{array}$ \\
\hline & & $\begin{array}{l}\text { „[...] kritinị mąstymą svarbu išsiugdyti ir plètoti vien jau dèl to, } \\
\text { kad būtų sklandesnis dialogas tarp konsultanto ir kliento [...] O } \\
\text { kritinị mąstymą galima plètoti ji praktiškai taikant konsultavimo } \\
\text { metu, nebūtina važiuoti į specialius mokymus“ }(\mathrm{K} 8)\end{array}$ \\
\hline & $\begin{array}{l}\text { Konsultantų savęs } \\
\text { įsivertinimas }\end{array}$ & $\begin{array}{l}\text { „[...] kritini mąstymą plètoti svarbu, kad galètų patys save } \\
\text { isivertinti ir savo veiklą analizuoti }[\ldots]^{\prime \prime}(\mathrm{K} 1)\end{array}$ \\
\hline & \multirow[t]{5}{*}{ Klientų ịvertinimas } & ,[...] kritinio mąstymo reikia, kad įvertinti klientą [...]“ (K1) \\
\hline & & $\begin{array}{l}\text { „[...] kritinis mąstymas padeda surasti daugiau pagristų } \\
\text { argumentų apie ką?" (K3) }\end{array}$ \\
\hline & & $\begin{array}{l}\text { „kritinio mąstymo pagalba gali klientui rasti kuo geriausius } \\
\text { variantus realizuoti save esamoje socialineje aplinkoje }[\ldots]^{\circ} \\
(\mathrm{K} 4)\end{array}$ \\
\hline & & $\begin{array}{l}\text { „[...] jei turi kritini mąstymą, tai tikrai gali ịsigilinti ị kliento } \\
\text { problemą ir jam padetti }[\ldots]{ }^{\circ}(\mathrm{K} 8)\end{array}$ \\
\hline & & 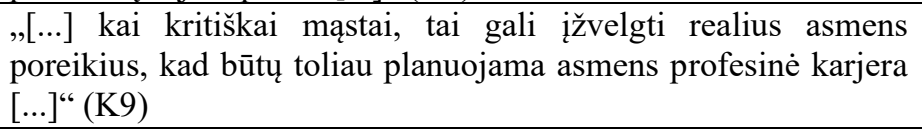 \\
\hline & $\begin{array}{l}\text { Profesinio pasitikëjimo } \\
\text { igijimas }\end{array}$ & $\begin{array}{l}\text { „[...] kritinio mąstymo pagalba sukuriamas pasitikèjimas ir } \\
\text { parodomas profesionalumas“ }(\mathrm{K} 2)\end{array}$ \\
\hline & \multirow[t]{2}{*}{$\begin{array}{l}\text { Klientams svarbios } \\
\text { informacijos perteikimas }\end{array}$} & $\begin{array}{l}\text { „[...] klientų supažindinimas su informacija, jos pagrindimas bei } \\
\text { perteikimas neįmanomas be konsultanto kritinio mąstymo“ (K3) }\end{array}$ \\
\hline & & $\begin{array}{l}\text { „[...] kritinio mąstymo dèka teisingų klausimų uždavimas } \\
\text { klientui leidžia gauti teisingą ir reikalingą informaciją iš } \\
\text { kliento“ (K8) }\end{array}$ \\
\hline & \multirow[t]{4}{*}{$\begin{array}{l}\text { Konsultantų kokybiškos } \\
\text { veiklos atlikimas }\end{array}$} & $\begin{array}{l}\text { „[...] kritinis mąstymas ịgalina visapusiškai ir kokybiškai atlikti } \\
\text { užduotis }[\ldots] \text { “.. }(\mathrm{K} 4)\end{array}$ \\
\hline & & $\begin{array}{l}\text { „[...] kritinis mąstymas ir jo plètojimas - raktas i sėkmingą } \\
\text { darbą“ (K5) }\end{array}$ \\
\hline & & $\begin{array}{l}\text { „[...]kritinis mąstymas padeda tikslingai nukreipti klientą tikslo } \\
\text { siekimui }[\ldots]^{\prime c}(\mathrm{~K} 7)\end{array}$ \\
\hline & & $\begin{array}{l}\text { „konsultantas, kritiškai mąstantis, nepriima sprendimų už } \\
\text { asmenị (K8) }\end{array}$ \\
\hline
\end{tabular}

Šaltinis: sudaryta autorių pagal atlikto tyrimo duomenis, 2021 
Išanalizavus tyrimo duomenis (4 lentelè), paaiškèjo, jog kritinio mąstymo taikymo svarba siejama su konsultantų tobulejjimu savo veikloje. Pasak tyrimo dalyvių, kritinio mąstymo taikymas padeda jiems ,,[...] tobulèti $[\ldots]$ “. $(\mathrm{K} 1),,,[\ldots]$ save įsivertinti $[\ldots]$ “ $(\mathrm{K} 1),,,[\ldots]$ ịvertinti klientą $[\ldots]$ ]“ $(\mathrm{K} 1)$, ,[...] įžvelgti realius jo poreikius [...]“ (K9), padeda sukurti ir palaikyti ,,...] sklandesni dialogą tarp konsultanto ir kliento [...]“ (K8) ir kt. Tyrimo dalyviai pabrèžia kritinio mąstymo taikymo svarbą, aktualizuodami, jog konsultantui taikant kritini mąstymą, ,[...] sukuriamas pasitikejjimas ir parodomas jo profesionalumas“ (K2). Galima teigti, jog konsultantui profesionaliai aptarnaujant klientą sukuriamas abipusis ryšys ir klientas labiau pasitiki konsultantu, patiki jam savo lūkesčius dèl profesinio mokymosi ar darbo pasiūlymų. Išimtinais atvejais klientui išreiškus savo aiškius motyvus, lūkesčius ir tikslus, paliekama teisė savarankiškai vykdyti darbo paiešką ar rinktis profesinị mokymąsi - taip tik patvirtinant užsimezgusị patikimumo ryšị tarp kliento ir konsultanto. Svarbu išklausyti, leisti klientui pačiam nuspręsti užduodant atitinkamus klausimus, o tai padaryti nenaudojant kritinio mąstymo konsultantui būtų sunkiai ịveikiama užduotis. Kritinis mąstymas yra vienas svarbesnių konsultanto profesionalumo elementų, todèl ji taip svarbu taikyti praktikoje.

Tyrimo metu taip pat paaiškejjo, jog kritinio mąstymo taikymas siejamas su klientams svarbios informacijos pateikimu, nes, pasak tyrimo dalyvių, konsultantui kritinis mąstymas ,[...] leidžia gauti teisingą ir reikalingą informaciją iš kliento“ (K8), „kokybiškai atlikti konsultavimo užduotis [...]“ (K4), ,[...] tikslingai nukreipti klientą tikslo siekimui [...]“ (K7) ir kt. Todèl galima teigti, kad kritinis mąstymas konsultantui reikalingas dèl įvairių priežasčių: kliento informacijos patikimumui įvertinti, gebėti spręsti sudėtingas problemas, kritiškai vertinti aplinkybes, pasverti alternatyvias nuomones, priimti nuoseklius sprendimus.

Remiantis Kumar'o ir James'o (2015) tyrimo duomenimis, būtent kritinis mąstymas skatina darbuotoją atsakingai priimti sprendimus ir spręsti problemas, nes jo pagrindą sudaro gebėjimas analizuoti, kurti naujas idèjas, daryti pagrịstas išvadas, apibendrinimus. Kaip akcentuojama (Užimtumo tarnybos kokybės vadovas, 2020), kritinio mąstymo taikymas padeda konsultantui priimti nešališkus sprendimus, igyvendinti keliamus aptarnavimo reikalavimus, surinkti informaciją apie paslaugų vartotojų lūkesčius. Todèl konsultanto kritinio mąstymo taikymas svarbus ir prasmingas ne tik jam pačiam, bet ir klientui bei organizacijai.

Taip pat buvo aktualu išsiaiškinti tyrimo dalyvių nuomonę, kokiais gebejjimais išsiskiria užimtumo tarnybos konsultantas, turintis kritini mąstymą. Gauti tyrimo rezultatai sugrupuoti i kategoriją „Konsultanto, turinčio kritini mąstymą, gebèjimai“ ir i 7 subkategorijas: „Pozityvus mąstymas“, „Kylančių klausimų analizavimas“, „Besikeičiančios situacijos vertinimas“, „Problemu išsprendimas“, „Profesionalus ir atsakingas veiklos atlikimas“, „Kliento skatinimas analizuoti asmeninę situaciją“, „Komunikacija, klausymasis bei ịtikinèjimas“( 5 lentelè).

Tyrimo metu paaiškejjo (5 lentelè), jog konsultantas, turintis kritinio mąstymo kompetenciją, pasižymi ịvairiais gebejjimais: ,[...] pozityviu mąstymu ir empatiškumu, gebejjimu išsamiai analizuoti ir apibendrinti, padaryti išvadas $[\ldots]^{“}(\mathrm{~K} 5)$, ,vertinti $[\ldots]$ besikeičiančią situaciją $[\ldots]$ “ $(\mathrm{K} 1),,[\ldots]$ priimti sprendimus“ (K5) ir kt., kas itin aktualu konsultuojant klientą, nes visada gaunama nauja informacija, igaunama nauja patirtis, kurią reikia išanalizuoti ir permąstyti. Gauti informantų atsakymai rodo, kad profesionaliam konsultantui būdingi ịvairūs ir aukšto lygio gebèjimai: kritiškai mąstantis konsultantas visų pirma geba ,[...] skatinti klientą analizuoti, suvokti savo asmeninę situaciją, priimti savarankiškus sprendimus [...]“ (K5) bei pasižymi ,[...] aukšto lygio komunikaciniais igūdžiais, gebèjimu klausytis bei įtikinti [...]““ (K7). Šiuo aspektu derètų paminèti, jog konsultantas, bendraudamas su besikreipiančiuoju, išskiria pokalbio esmę ir patikrina gaunamą informaciją, ją analizuoja, apdoroja, pritaikydamas savo kritini mąstymą, ir tokiu būdu vykdydamas savo kaip profesionalo funkcijas bei keliamus reikalavimus konsultavimo veiklai.

Remiantis Adomaitienès ir Balčiūnienès (2017) tyrimo duomenimis, asmenys, dirbantys socialinių paslaugų sektoriuje, turi turèti specifinių žinių, gebẻjimų, igūdžių ir ịpročių, nuolat ugdyti ir plètoti reikšmingas minètai veiklai kompetencijas, vertybines nuostatas. Tai liudija, jog nors konsultantas turi kritinio mąstymo gebejjimų, bet jis privalo nuolatos juos tobulinti, kadangi klientui reikalinga suteikti profesionalią, aukštos kokybès konsultaciją. Svarbu akcentuoti, jog kritinio mąstymo sąlygojami sprendimai, priimami konsultantų, turi būti nešališki ir priimami abejoms pusėms 
tinkami, siekiant igyvendinti keliamus aptarnavimo reikalavimus, nuolat renkant informaciją apie paslaugų vartotojų lūkesčius, periodiškai vykdant klientų apklausas apie darbo rinkos paslaugų, užimtumo rèmimo ir kitų priemonių teikimą, renkant informaciją apie pokyčius darbo rinkoje ir kt.

5 lentelè. Konsultanto, turinčio kritinị mąstymą, gebèjimai

\begin{tabular}{|c|c|c|}
\hline Kategorija & Subkategorija & Patvirtinantis teiginys \\
\hline \multirow{21}{*}{$\begin{array}{l}\text { Konsultanto, turinčio } \\
\text { kritinị mąstymą, } \\
\text { gebejjimai }\end{array}$} & \multirow[t]{4}{*}{ Pozityvus mąstymas } & „Išsiskiria teigiamomis emocijomis, pozityvu [...]“ $(\mathrm{K} 1)$ \\
\hline & &,$[\ldots]$ pasireiškia empatija klientui $[\ldots]$ “.. (K2) \\
\hline & & „[...] susijęs su empatiškumu [...]“ $(\mathrm{K} 4)$ \\
\hline & & „[...] jam svarbu empatija, atvirumas [...]“" (K6) \\
\hline & \multirow{3}{*}{$\begin{array}{l}\text { Kylančių klausimų } \\
\text { analizavimas }\end{array}$} &,$[\ldots]$ geba įvairius klausimus analizuoti [...]““ (K1) \\
\hline & &,$[\ldots]$ informacijos analizavimo gebèjimas $[\ldots]^{“ *}(\mathrm{~K} 3)$ \\
\hline & & $\begin{array}{l}\text {,[...] turi gebèjimą analizuoti, apibendrinti, padaryti išvadas } \\
{[\ldots] \text { (K5) }}\end{array}$ \\
\hline & \multirow[t]{3}{*}{$\begin{array}{l}\text { Besikeičiančios situacijos } \\
\text { vertinimas }\end{array}$} & $\begin{array}{l}\text { „[...] suvokia besikeičiančią situaciją darbo rinkoje, stebi požiūrị } \\
\text { i darbą, analizuoja, vertina }[\ldots] \text {... }(\mathrm{K} 1)\end{array}$ \\
\hline & & $\begin{array}{l}\text { „[...] geba pagrịstai ir atsakingai siūlyti sprendimus ịvairioms } \\
\text { situacijoms“(K2) }\end{array}$ \\
\hline & & $\begin{array}{l},[\ldots] \text { turi gebejjimą ịvairiapusiškai analizuoti ir ịvertinti situaciją } \\
{[\ldots] \text { [... (K5) }}\end{array}$ \\
\hline & \multirow[t]{4}{*}{ Problemų išsprendimas } & „[...] būdingas problemų svarstymas, jų išsprendimas [...]“ (K3) \\
\hline & & ,[...] geba pats padaryti išvadas ir priimti sprendimus“ (K5) \\
\hline & & „[...] pasižymi gebėjimu spręsti ir išspręsti problemas“ (K7) \\
\hline & & $\begin{array}{l}\text {,[...] išsiaiškina tikrus asmens poreikius, ieško būdų, kaip } \\
\text { padėti“ }(\mathrm{K} 9)\end{array}$ \\
\hline & \multirow[t]{3}{*}{$\begin{array}{l}\text { Profesionalus ir atsakingas } \\
\text { veiklos atlikimas }\end{array}$} & $\begin{array}{l}\text {,[...] būdingas profesionalumas, patikimumas ir atsakingumas“ } \\
(\mathrm{K} 4)\end{array}$ \\
\hline & & $\begin{array}{l}{[\ldots] \text { geba prisiimti asmeninę atsakomybę už priimtus }} \\
\text { sprendimus [...]" (K5) }\end{array}$ \\
\hline & & $\begin{array}{l}\text { „[...] sistemingas informacijos apdorojimas, loginis mąstymas } \\
\text { pasireiškia }[\ldots] \text { "... }(\mathrm{K} 8)\end{array}$ \\
\hline & $\begin{array}{l}\text { Kliento skatinimas } \\
\text { analizuoti asmeninę situaciją }\end{array}$ & $\begin{array}{l}\text { „[...] geba skatinti klientą analizuoti, suvokti savo asmeninę } \\
\text { situaciją, priimti asmeninius sprendimus }[\ldots] \text { (... (K5) }\end{array}$ \\
\hline & \multirow[t]{3}{*}{$\begin{array}{l}\text { Komunikacija, klausymasis } \\
\text { bei ịtikinejjimas }\end{array}$} & $\begin{array}{l}\text { „[...] pasižymi gerais komunikaciniais igūdžiais, gebejjimu } \\
\text { klausytis ir išgirsti, gebejjimu įtikinti [...]“ (K7) }\end{array}$ \\
\hline & & $\begin{array}{l}\text { „[...] būdinga ,turtingesne““ iškalba, gebèjimas sklandžiai dèstyti } \\
\text { mintis }[\ldots] \text { [.. }(\mathrm{K} 8)\end{array}$ \\
\hline & & $\begin{array}{l}\text { „[...] ìvaldytas gebèjimas efektyviai klausyti ir komunikuoti, } \\
\text { ¡žvalgumas }[\ldots] \text {... }(\mathrm{K} 8)\end{array}$ \\
\hline
\end{tabular}

Šaltinis: sudaryta autorių pagal atlikto tyrimo duomenis, 2021

Atliekant tyrimą itin aktualu buvo atskleisti, kokie, tyrimo dalyvių nuomone, yra efektyviausi kritinio mąstymo taikymo būdai ir priemonès. Tyrimo dalyvių atsakymai sugrupuoti ì kategoriją „Efektyviausi konsultantų kritinio mąstymo taikymo būdai ir priemonès“ ir ị 4 subkategorijas: „Profesinès veiklos refleksija“, „Savišvieta, saviugda“, „Racionalus informacijos analizavimas“, „Praktinis problemų sprendimas“ (6 lentelè). Gailiaus ir kt. (2013) tyrimo duomenimis, efektyviausi ir pagrindiniai kritinio mąstymo taikymo būdai ir priemonès profesinèje veikloje yra profesinès veiklos refleksija, skatinanti nuolat vertinti ir tobulinti savo veiklą, reflektyvus problemų sprendimas, kuomet sudètinga priimti teisingą sprendimą, teorinių žinių pritaikymas praktikoje, profesinis tobulëjimas, nuolatinis mokymasis. Pasak šio tyrimo dalyvių (6 lentelè), efektyvus kritinio mąstymo taikymo būdas taip pat yra profesinès veiklos refleksija, kuomet konsultantas reflektuojant geba ,[...] daryti pagrịstas išvadas [...], mokosi iš savo patirties [...]" (K1) ir kt. Svarbu pažymèti, jog apmąstymas ir apibendrinimas yra kritinio mąstymo pagrindas, skatinantis nuolat mąstyti bei ieškoti prasmès. Iš tyrimo išryškejjo, jog informantų laikytina kaip efektyvu taikant kritini mąstymą ,racionalus informacijos analizavimas, kliento fizinès, psichologinès būklès ịvertinimas, kompetencijų, gebèjimų, polinkių analizė $[\ldots]$ “. (K4), ,[...] îsigilinimas ị kliento problemą ir praktinis jos sprendimas“ (K7). Tai 
rodo, kad tyrime dalyvavę konsultantai reflektuoja profesinę veiklą, siekia tobulèti bei dalintis patirtimi, vertinti klientų poreikius, gebèjimus bei daryti pagrịstas išvadas. Visi konsultantai pabrèžia, kad dalijimasis savo darbo patirtimi yra labai svarbus jų tobulèjimo aspektas, nes mokymasis iš kito patirties yra neịkainojamas mokymasis nekartoti tų pačių klaidų, kurios gali turèti neigiamos įtakos konsultavimo kokybei.

\section{6 lentelè. Efektyviausi konsultantų kritinio mąstymo taikymo būdai ir priemonès}

\begin{tabular}{|c|c|c|}
\hline Kategorija & Subkategorija & Patvirtinantis teiginys \\
\hline \multirow{18}{*}{$\begin{array}{c}\text { Efektyviausi kritinio } \\
\text { mąstymo taikymo } \\
\text { būdai ir priemonès }\end{array}$} & \multirow[t]{5}{*}{ Profesinès veiklos refleksija } & $\begin{array}{l}\text { „,...] užduoti sau atitinkamus klausimus ir tik tada reflektuojant } \\
\text { daryti tam tikras išvadas }[\ldots] \text { “.. }(\mathrm{K} 1)\end{array}$ \\
\hline & &,$[\ldots]$ patirtinis mokymasis $[\ldots] “(\mathrm{~K} 1)$ \\
\hline & & $\begin{array}{l}\text {,[...] neigiamų (o ir teigiamų) pavyzdžių analizè, mokymasis iš } \\
\text { savo ir kitų patirties [...]“ (K2) }\end{array}$ \\
\hline & & ,[...] mokymasis iš gerųų ir blogųjų patirčių [...]“" $(\mathrm{K} 1)$ \\
\hline & & ,[...] savianalizè $[\ldots]^{“}(\mathrm{~K} 5)$ \\
\hline & \multirow[t]{6}{*}{ Savišvieta, saviugda } & „Tinkamas būdas - savišvieta, saviugda [...]““ (K1) \\
\hline & &,$[\ldots]$ motyvacija tobulèti $[\ldots] “(\mathrm{~K} 1)$ \\
\hline & & ,[...] saviugda $[\ldots] “(\mathrm{~K} 2)$ \\
\hline & & ,[...] noras tobulèti šioje srityje, dalintis patirtimi $[\ldots]^{\prime “}(\mathrm{~K} 1)$ \\
\hline & & $\begin{array}{llll}{[\ldots] \text { nuolatinis mokymasis, }} & \text { domèjimasis, literatūros } \\
\text { studijavimas, skaitymas }[\ldots] “(\mathrm{~K} 5) & & \\
\end{array}$ \\
\hline & & $\begin{array}{l}\text { „[...] domėjimasis, bendravimas, analizavimas, keitimasis } \\
\text { informacija“ (K5) }\end{array}$ \\
\hline & \multirow{4}{*}{$\begin{array}{l}\text { Racionalus informacijos } \\
\text { analizavimas }\end{array}$} &,$[\ldots]$ racionaliai įvertinti informaciją, kuri atitinka tikrovę“ $(\mathrm{K} 3)$ \\
\hline & & $\begin{array}{l}\text { „kliento fizinès, psichologinès būklès ìvertinimas, } \\
\text { kompetencijų, gebèjimų, polinkių analizè }[\ldots]^{“}(\mathrm{~K} 4)\end{array}$ \\
\hline & & $\begin{array}{l}\text {,[...] situacijos analizè užduodant ịvairius klausimus, situacijos } \\
\text { vertinimas, paslaugų pritaikymas kliento situacijai [...]“ (K6) }\end{array}$ \\
\hline & & ,[...] diskusija, informacijos patikrinimas [...] $]^{“(K 8)}$ \\
\hline & \multirow[t]{3}{*}{$\begin{array}{l}\text { Praktinis problemų } \\
\text { sprendimas }\end{array}$} & $\begin{array}{l}\text { „[...] pateikiant praktini problemų sprendimo igyvendinimo } \\
\text { planą }[\ldots] \text { (... }(\mathrm{K} 3)\end{array}$ \\
\hline & & ,[...] įsigilinimas į kliento problemą“ (K7) \\
\hline & & „[...] pasiūlyti tinkamiausi problemų sprendimo būdai“ (K9) \\
\hline
\end{tabular}

Šaltinis: sudaryta autorių pagal atlikto tyrimo duomenis, 2021

Taip pat tyrimo dalyviai nurodè, kad efektyvus kritinio mąstymo taikymo būdas yra „savišvieta, saviugda $[\ldots]^{\prime \prime}(\mathrm{K} 1)$, ,[...] nuolatinis mokymasis, domèjimasis skaitant specializuotą literatūrą, dalyvaujant mokymuose, kursuose, seminaruose bei tobulejjimas [...]“ (K5). Tai patvirtina, kad suaugusiujų švietimas yra grịstas savarankišku mokymusi, analizuojant mokslinę literatūrą, dalyvaujant mokymuose, konferencijose, seminaruose ir kt. Pastebètina, jog kritinio mąstymo kompetencija igyjama mokymosi ir praktinio darbo procese, t. y. neatsiejama nuo saviugdos, mokymosi darbo vietoje, patirtinio, neformaliojo mokymosi ir kt.

Paskutiniu interviu klausimu buvo siekiama išsiaiškinti, kokius būdus ir priemones naudoja tyrimo dalyviai, igyvendindami kritinio mąstymo taikymą. Tyrimo dalyvių atsakymai sugrupuoti $\mathfrak{i}$ kategoriją „Naudojami būdai ir priemonès, igyvendinant kritinio mąstymo taikymą" ir i 4 subkategorijas: „Profesinès veiklos refleksija“, „Patirties dalinimasis su kolegomis“, „Tikslinga komunikacija su klientu“, „Savišvieta, saviugda“ (7 lentelè). Kaip matyti 7 lentelèje, vienas iš būdų, naudojamų igyvendinant kritinio mąstymo taikymą, yra profesinès veiklos refleksija, tai patvirtina

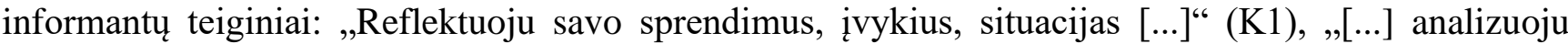
savo patirti $[. . .]^{\text {" }}$ (K7) ir kt. Svarbu akcentuoti, jog profesinès veiklos refleksija skatina konsultantą pergalvoti idejas, prasmes, interpretuoti ịvairias situacijas, taikyti savo patirtị bei ieškoti naujos patirties. Remiantis Ford'o ir Yore (2012) tyrimo išvadomis, galima paantrinti, jog kritinis mąstymas yra refleksijos procesas, tai diskusija su pačiu savimi, tai reflektyvus problemų sprendimo procesas, kuomet sudètinga priimti vieną teisingą atsakymą. Siekiant užtikrinti konsultavimo paslaugų kokybę, 
konsultantui reikšmingas kritinio mąstymo taikymas darbo vietoje, kasdienio konsultavimo metu, nuolat vertinant priimtus problemų sprendimus, kiekvieno kliento individualią situaciją ir kt.

7 lentelè. Konsultantų naudojami būdai ir priemonès, ịgyvendinant kritinio mąstymo taikymą

\begin{tabular}{|c|c|c|}
\hline Kategorija & Subkategorija & Patvirtinantis teiginys \\
\hline \multirow{16}{*}{$\begin{array}{l}\text { Būdai ir priemonès, } \\
\text { igyvendinant kritinio } \\
\text { mąstymo taikymą }\end{array}$} & \multirow[t]{5}{*}{ Profesinès veiklos refleksija } & „Reflektuoju savo sprendimus, ivykius, situacijas [...]“ (K1) \\
\hline & &,$[\ldots]$ aplinkybių analizavimas $[\ldots]$ ]“ (K5) \\
\hline & & ,[...] situacijų analizè [...]“" (K6) \\
\hline & & ,[...] analizè savo patirties [...]“ $(\mathrm{K} 7)$ \\
\hline & & „[...] savianalizė [...]“ (K5) \\
\hline & \multirow{5}{*}{$\begin{array}{l}\text { Patirties dalinimasis su } \\
\text { kolegomis }\end{array}$} & „Vidinė komunikacijos sistema [...]“ $(\mathrm{K} 1)$ \\
\hline & & $\begin{array}{l}\text { „[...] bendravimas su kolegomis, situacijų analizè grupèje } \\
{[\ldots] \text { (K1) }}\end{array}$ \\
\hline & & $\begin{array}{l}\text { „[...] bendradarbiavimas su vadovybe ir su kolegomis }[\ldots]^{“ 6} \\
(\mathrm{~K} 2)\end{array}$ \\
\hline & &,$[\ldots]$ diskusijos $[\ldots]^{“}(\mathrm{~K} 5)$ \\
\hline & & ,[...] konsultacijos su kolegomis [...]“ (K6) \\
\hline & \multirow[t]{3}{*}{$\begin{array}{l}\text { Tikslinga komunikacija su } \\
\text { klientu }\end{array}$} & 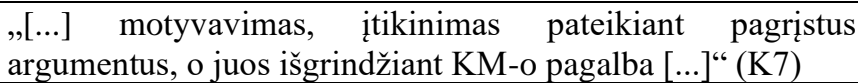 \\
\hline & & $\begin{array}{l}\text {,[...] konsultavimas, paremtas tiksliais klausimais, klientui } \\
\text { pateikiami situacijos galimi variantai, sprendimo būdai }[\ldots]]^{\circ} \\
(\mathrm{K} 8)\end{array}$ \\
\hline & & $,[\ldots]$ klausdama išsiaiškinu asmens poreikius $[\ldots]]^{“}(\mathrm{~K} 9)$ \\
\hline & \multirow[t]{3}{*}{ Savišvieta, saviugda } & „,[...] naujienos, intranetas [...]““(K1) \\
\hline & & $\begin{array}{l}\text {,[...] edukologijos, psichologijos, ekonomikos, verslo raidos } \\
\text { analizès“ }(\mathrm{K} 4)\end{array}$ \\
\hline & & ,[...] mokymasis, domėjimasis“ (K5) \\
\hline
\end{tabular}

Šaltinis: sudaryta autorių pagal atlikto tyrimo duomenis, 2021

Tyrimo metu taip pat paaiškejjo (7 lentelè), jog igyvendinti konsultantams kritinio mąstymo taikymą padeda ,[...] bendravimas su kolegomis, situacijų, atvejų analizè grupèse $[\ldots]^{] “}(\mathrm{~K} 1),,[\ldots]$ diskusijos [...]“ (K5), ,[...] konsultacijos su kolegomis, tikslinga komunikacija su klientu [...]“ (K6) ir kt. Svarbu pažymėti, jog konsultantams, igyvendinant kritinio mąstymo taikymą, būtina konsultavimo procese laikytis bendradarbiavimo nuostatos tiek su kolegomis, tiek su klientais, taip užtikrinant grįžtamajji ryšį, patirties pasidalijimą bei efektyvų problemų sprendimą. Kita vertus, sèkmingam konsultantų kritinio mąstymo taikymo realizavimui būtinas komandos narių tarpusavio pasitikèjimas bei atviras, konstruktyvus bendravimas su kolegomis ir klientais, jų subūrimas efektyviai konsultacinei veiklai, pokyčių ịgyvendinimas, pagarbus požiūris ị skirtingus žmones ir kt. Svarbu pastebėti ir tai, jog atskiram konsultantui nepakanka vien tik mąstyti, reikia galvoti, kaip mąstai, kodèl taip mąstai, kaip tavo mąstymas gali paveikti kitą asmeni, svarbu nuolat domètis, mokytis, tobulèti, nes tai suteikia naujų žinių, patirties, keičia vertybes bei nuostatas. Apibendrintai galima teigti, kad tyrimo dalyviai, igyvendindami kritinio mąstymo taikymą, reflektuoja savo profesinę veiklą, dalijasi patirtimi su kolegomis, tikslingai konsultuoja klientus, užsiima savišvieta ir saviugda.

Apibendrinant konsultantų kritinio mąstymo taikymo tyrimo duomenų analizę, galima teigti, jog kritinio mąstymo taikymo svarba bei prasmè užimtumo tarnyboje dirbantiems konsultantams susijusi su jų tobulèjimu praktinèje veikloje, kokybišku veiklos atlikimu, savęs įsivertinimu, klientų ịvertinimu, profesinio pasitikejjimo igijimu, klientams svarbios informacijos perteikimu. Konsultantas, turintis kritinio mąstymo kompetenciją, pasižymi pozityviu mąstymu, gebẻjimu analizuoti kylančius klausimus, vertinti besikeičiančią situaciją, profesionaliai ir atsakingai atlikti savo užduotis, skatinti klientą analizuoti asmeninę situaciją, gebejjimu klausytis bei ịtikinti klientą. Efektyviais kritinio mąstymo taikymo būdais ir priemonėmis laikytina profesinès veiklos refleksija, savišvieta, saviugda, racionalus informacijos analizavimas, praktinis problemu sprendimas. Igyvendindami kritinio mąstymo taikymą konsultantai reflektuoja savo profesinę veiklą, dalijasi patirtimi su kolegomis, tikslingai konsultuoja klientus, užsiima savišvieta ir saviugda. 


\section{Išvados}

1. Kritinis mąstymas yra aukštesnio lygmens mąstymas, susietas su nauja patirtimi ir žiniomis, skatinantis ateities veiksmų modeliavimą, reflektyvų problemų sprendimą darant pagrịstas išvadas, išanalizavus veiklos problemas. Siekiant išlaikyti kokybišką konsultavimo paslaugą, reikia nuolatinių konsultanto pastangų taikyti kritinį mąstymą, ne tik suvokiant kliento požiūrị ị darbo rinką ar norą keisti profesiją, bet ir padedant igyvendinti jo siekius, siekiant išvengti konfliktinių situacijų ir kt.

2. Tyrimo rezultatų analizė rodo, jog kritinio mąstymo prasmę užimtumo tarnyboje dirbantys konsultantai suvokia, nes sieja su tobulejjimu praktinèje veikloje, kokybišku veiklos atlikimu, savęs įsivertinimu, klientu ịvertinimu, profesinio pasitikejimo igijimu, klientams svarbios informacijos perteikimu. Empiriniai duomenys atskleidžia, jog kritinis mąstymas konsultanto veikloje yra itin svarbus siekiant pasiūlyti klientui efektyvias mokymosi, tobulejjimo, įsidarbinimo formas, būdus, metodus, priemones, padeda pažinti klientą ir padèti jam pažinti save, savo stipriąsias ir silpnąsias puses, turimus ir trūkstamus šaltinius, skatina konsultantą reflektuoti, suteikti konstruktyvų ir efektyvų grịžtamaji ryši, nuolat mokytis ir tobulinti savo veiklą. Kaip rodo atliktas tyrimas, užimtumo tarnyboje dirbančių konsultantų kritinis mąstymas svarbus konsultavimo kokybei, veiksmingo grį̌zamojo ryšio teikimui, patirties refleksijai, savęs pažinimui, savo privalumų, trūkumų ir tobulintinų veiklos aspektų analizei. Siekiant užtikrinti konsultavimo paslaugų kokybę, būtini konsultantui kritinio mąstymo gebejimai, skatinantys nuolat vertinti ir tobulinti savo veiklą, numatyti profesinio tobulejjimo perspektyvą. Konsultanto veiklos kokybę lemia kritinio mąstymo gebejjimai: pozityvus mąstymas, gebejjimas analizuoti kylančius klausimus, vertinti besikeičiančią situaciją, profesionaliai ir atsakingai atlikti savo užduotis, skatinti klientą analizuoti asmeninę situaciją, klausytis bei padèti apsispręsti. Efektyviais kritinio mąstymo igyvendinimo veiksniais laikytini profesinès veiklos refleksija, savišvieta, saviugda, racionalus informacijos analizavimas, praktinis problemų sprendimas. Taikydami kritinį mąstymą konsultantai reflektuoja savo profesinę veiklą, dalijasi patirtimi su kolegomis, konsultuoja klientus, užsiima savišvieta ir saviugda, planuoja, koordinuoja, realizuoja konsultavimo procesus, tenkina konsultuojamujų poreikius, nustato mokymosi poreikius, užtikrina grịžtamaji ryšị.

\section{Literatūros sąrašas}

1. Adomaitienè, J. ir Balčiūnienè, R. (2017). Asmenų, dirbančių socialinių paslaugų sektoriuje, kompetencijos ir jų tobulinimo galimybès. Andragogika, 1 (8).

2. Beachboard, M. B., Beachboard, J. LI., W., \& Adkinson, S. (2011). Cohorts and Relatedness: SelfDetermination Theory as an Explanation of How Learning Communities Affect Educational Outcomes. Research In Higher Education, 52(8), 853-874.

3. Facione, P. A., Facione, N. C., \& Giancarlo, C. A. (2010). The Disposition Toward Critical Thinking: Its Character, Measurement, and Relationship to Critical Thinking Skill, Informal Logic, $20(1), 61-84$.

4. Ford, C. L., \& Yore, L. D. (2012). Toward convergence of metacognition, reflection, and critical thinking: Illustrations from natural and social sciences teacher education and classroom practice. Metacognition in science education: Trends in current research. In A. Zohar \& J. Dori (Eds.). Dordrecht, The Netherlands. Springer, 251-271.

5. Gailius, Ž., Malinauskas, D., Petkauskas, L. ir Ragauskas, L. (2013). Darbo su jaunimo grupemis vadovas. Neformaliojo ugdymo praktika Lietuvoje. Vilnius: Švietimo aprūpinimo centras.

6. Gaižauskaitè, I. ir Valavičienè, N. (2016). Socialiniu tyrimu metodai: kokybinis interviu. Vilnius: Mykolo Romerio universitetas.

7. Halpern, D. F. (2014). Thought and knowledge: an introduction to critical thinking. (5th ed.). New York, NY, US: Psychology Press.

8. Helsdingen, A., Van Gog, T., \& Van Merrienboer, J. (2011). The Effects of Practice Schedule and Critical Thinking Prompts on Learning and Transfer of a Complex Judgment Task. Journal of Educational Psychology, 103(2), 383-398. 
9. Huang, G. C., Lindell, D., Jaffe, L. E., \& Sullivan, A. M. (2016). A multi-site study of strategies to teach critical thinking: „Why do you think that?" Medical Education, 50, 236-249.

10. Ku, K. Y. L., Kit-Tai Hau, E. H., \& Lai, C. M. (2014). Integrating direct and inquiry-based instruction in the teaching of critical thinking: an intervention study. Hong Kong: Hong Kong Education Bureau.

11. Kumar, R., \& James, R. (2015). Evaluation of Critical Thinking in Higher Education in Oman. International Journal of Higher Education, 4(3), 33-43.

12. Lietuviu kalbos žodynas (2020). (žiūrèta $2021 \mathrm{~m}$. birželio 5 d. ). Prieiga per internetą (http://www.lkz.lt/?zodis=kritinis\&id=17217840000).

13. Loes, CH. N., \& Pascarella, E. (2017). Collaborative Learning and Critical Thinking: Testing the Link. The Journal of Higher Education, 88(5), 1-27.

14. Paul, R., \& Elder, L. (2012). Critical Thinking: Tools for Taking Charge of Your Learning and Your Life. Boston: Pearson Education.

15. Penkauskienė, D. (2016). Socialinio darbo didaktika. Kritinio ir kūrybinio mastymo sąsaja. MRU, 90-104.

16. Proceedings of the International Business Conference 2016: Searching for Innovative and Creative Business Solutions (žiūrèta $2021 \mathrm{~m}$. birželio 2 d.). Prieiga per internetą (https://www.viko.lt/media/uploads/sites/3/2016/07/9786094360428.pdf).

17. Tiruneh, D. T., De Cock, M., Weldeslassie, A. G., Elen, J., \& Janssen, R. (2017). Measuring Critical Thinking in Physics: Development and Validation of a Critical Thinking Test in Electricity and Magnetism. International Journal of Science and Mathematics Education, 15(4), 663-682.

18. Užimtumo tarnyba prie Lietuvos Respublikos socialinès apsaugos ir darbo ministerijos. Kokybès vadovas. $2020 \mathrm{~m}$. liepos $23 \mathrm{~d}$. Nr. V-282.

19. Vaicekauskienè, V. ir Čiužas, R. (2013). Reflektyviojo modelio taikymo teorinès prielaidos socialinių darbuotojų rengime. Socialinis ugdymas. Patirtis ir metodai, 2(34), 139-149.

20. Westfall, Ch. (2019). Leadership Survey: Over 77\% Of CEOs Are Looking For These Two Critical $\begin{array}{llllllll}\text { Skills } 9 & \text { (žiūrèta } 2021 & \mathrm{~m} \text {. birželio } 28 & \text { d.). Prieiga per interneta }\end{array}$ (https://www.forbes.com/sites/chriswestfall/2019/04/08/leadership-survey-ceoscritcalskills/\#15f5b1356d10).

21. Zafar, A., Zahra, N., \& Zia, Y. A. (2014). Antecedents of job burnout among bank employes. Humanities and social sciences, 21(2), 13-24.

22. Žydžiūnaitè, V. ir Sabaliauskas, S. (2017). Kokybiniai tyrimai. Principai ir metodai. Vilnius: Vaga.

\title{
APPLICATION OF CRITICAL THINKING SKILLS IN THE ACTIVITIES OF CONSULTANT
}

\author{
Dr. Gitana Tolutienè, Giedrè Būtėnienè
}

\section{Summary}

Investigation problem. This article seeks to answer the problematic questions: do enough employment service consultants understand the importance and meaning of applying critical thinking in counseling? what critical thinking skills affect the quality of a consultant's performance and what factors determine the implementation of critical thinking? what techniques and tools do you use to apply critical thinking?

Object of research: application of critical thinking in the aspect of consultant activity.

The aim of the research: to reveal the application of critical thinking in the aspect of the activity of consultant in the employment service.

Objectives of the research: 1) to analyze the theoretical concepts of the concept of critical thinking; 2) examine the application of critical thinking to the experience of consultants working in the employment service.

Research methods: theoretical analysis; qualitative research (partially structured interview).

The survey sample. 9 recruitment and employment support consultants of the employment service were selected for the qualitative research. Study participants were selected using a non-probabilistic selection method using a targeted selection strategy. The age of the study participants varies from 36 to 56 years, the average age is 46 years. The gender of all study participants is female, all have higher education and all work experience in the employment service is more than five years, i. y. ranges from 6 to 26 years, which reveals their professionalism in their professional activities.

The main results and conclusions of theoretical and empirical research. Critical thinking is a higher level of thinking related to new experiences and new knowledge that promotes the modeling of future actions, reflective problem 
solving by making informed conclusions after analyzing operational problems. Maintaining a quality counseling service requires a continuous effort by the counselor to apply critical thinking, not only understanding the client's attitude toward the job market or desire to change professions, but also helping to achieve his or her aspirations to avoid conflict situations and so on. The analysis of the research results shows that the meaning of critical thinking is perceived by the consultants working in the employment service, as it is related to improvement in practical activities, quality performance, selfassessment, client evaluation, gaining professional trust, and communicating important information to clients. Empirical data reveal that critical thinking in the activities of consultant is crucial to offer the client effective forms of learning, development, employment, methods, techniques, tools, helps to know the client and help him get to know himself, his strengths and weaknesses, available and missing resources, encourages the counselor to reflect, provide constructive and effective feedback, and continually learn and improve their performance. According to the research, the critical thinking of the consultants working in the employment service is important for the quality of counseling, providing effective feedback, reflection of experience, self-knowledge, analysis of one's strengths, weaknesses and areas for improvement. In order to ensure the quality of counseling services, the counselor needs critical thinking skills that encourage him / her to continuously evaluate and improve his / her activities, and to provide a perspective for professional development. The quality of consultant's work is determined by critical thinking skills: positive thinking, the ability to analyze emerging issues, assess the changing situation, perform their tasks professionally and responsibly, encourage the client to analyze the personal situation, listen and help make decisions. Effective factors of critical thinking implementation include professional reflection, self-education, self-education, rational analysis of information, and practical problem solving. Applying critical thinking, counselors reflect on their professional activities, share experiences with colleagues, consult clients, engage in self-education and self-education, plan, coordinate, implement counseling processes, meet the needs of clients, identify learning needs, provide feedback.

Keywords: critical thinking, consultant, employment service. 